\title{
Intercalative Stacking: A Critical Feature of DNA Charge-Transport Electrochemistry
}

\author{
Elizabeth M. Boon, ${ }^{\dagger}$ Nicole M. Jackson, ${ }^{\ddagger}$ Matthew D. Wightman, ${ }^{\ddagger}$ Shana O. Kelley, ${ }^{\dagger} \S$ \\ Michael G. Hill, $*,+$ and Jacqueline K. Barton $*, \dagger$ \\ Division of Chemistry and Chemical Engineering, California Institute of Technology, \\ Pasadena, California 91125, and Department of Chemistry, Occidental College, \\ Los Angeles, California 90041
}

Received: June 13, 2003

\begin{abstract}
In electrochemistry experiments on DNA-modified electrodes, features of the redox probe that determine efficient charge transport through DNA-modified surfaces have been explored using methylene blue $\left(\mathrm{MB}^{+}\right)$ and $\mathrm{Ru}\left(\mathrm{NH}_{3}\right)_{6}{ }^{3+}$ as DNA-binding redox probes. The electrochemistry of these molecules is studied as a function of ionic strength to determine the necessity of tight binding to DNA and the number of electrons involved in the redox reaction; on the DNA surface, $\mathrm{MB}^{+}$displays $2 \mathrm{e}^{-} / 1 \mathrm{H}^{+}$electrochemistry $(\mathrm{pH} 7)$ and $\mathrm{Ru}\left(\mathrm{NH}_{3}\right)_{6}{ }^{3+}$ displays $1 \mathrm{e}^{-}$electrochemistry. We examine also the effect of electrode surface passivation and the effect of the mode (intercalation or electrostatic) of $\mathrm{MB}^{+}$and $\mathrm{Ru}\left(\mathrm{NH}_{3}\right)_{6}{ }^{3+}$ binding to DNA to highlight the importance of intercalation for reduction by a DNA-mediated charge-transport pathway. Furthermore, in experiments in which $\mathrm{MB}^{+}$is covalently linked to the DNA through a $\sigma$-bonded tether and the ionic strength is varied, it is demonstrated that intercalative stacking rather than covalent $\sigma$-bonding is essential for efficient reduction of $\mathrm{MB}^{+}$. The results presented here therefore establish that efficient charge transport to the DNA-binding moiety in DNA films requires intercalative stacking and is mediated by the DNA base pair array.
\end{abstract}

\section{Introduction}

DNA has been extensively studied as a medium for charge transport. ${ }^{1-20}$ The DNA $\pi$-stack is capable of mediating oxidative DNA damage over long molecular distances in a reaction that is sensitive to DNA sequence-dependent conformation and dynamics. ${ }^{14-31}$ A mixture of tunneling and hopping mechanisms has been proposed to account for this long-range chemistry, which is gated by dynamical variations within the stack. ${ }^{32-49}$ DNA charge-transport chemistry may play a role within the cell, and indeed, oxidative damage to DNA from a distance has been demonstrated in nucleosome core particles, ${ }^{50}$ as well as in the cell nucleus. ${ }^{51}$

We have developed an electrochemical assay to probe and exploit charge transport through double-stranded-DNA-modified gold electrodes. ${ }^{52-59}$ The electrochemistry, binding affinity, and charge-transport dynamics of intercalated organic dyes at these electrodes have been examined. ${ }^{52,54,55}$ Noncovalent binding appears to be primarily constrained to the top of the densely packed DNA monolayer, as established previously with daunomycin ${ }^{55}$ and methylene blue. ${ }^{52}$ Electrochemical studies involving daunomycin site-specifically bound at various positions within DNA monolayers reveal that DNA-mediated charge transport proceeds over significant distances $(>35 \AA) .{ }^{54}$ While this reaction is not sensitive to distance, it is markedly attenuated by the presence of an intervening CA mismatch. Even very small perturbations in DNA base stacking and structure, including single base mismatches and other DNA base lesions, disrupt charge transport through these surfaces. ${ }^{54-56,58,59}$ Exploiting this sensitivity, we have developed assays for routine mismatch

\footnotetext{
* To whom correspondence should be addressed.

California Institute of Technology.

$\doteqdot$ Occidental College.

$\S$ Present address: Department of Chemistry, Boston College, Chestnut Hill, MA 02467.
}

detection based on this technology. We have also applied electrochemistry at DNA-modified electrode surfaces to probe DNA base stacking perturbations associated with DNA-protein binding and kinetics. ${ }^{58}$ Electrochemistry at DNA-modified surfaces provides an excellent tool for directly probing the base pair stack of DNA. ${ }^{56,58,59}$

DNA-based electrochemical methods have also been developed primarily to detect nucleic acid hybridization. ${ }^{44,45,60-73}$ Notably, those methods do not rely on an intercalator as the redox probe. General principles governing electron transport through modified films involving percolation or the physical displacement of associated ions are also well understood. ${ }^{74}$ In our experiments, DNA-based electrochemistry provides a means to study charge transport to a DNA intercalator mediated by the base pair stack. ${ }^{52-59}$ Photophysical experiments have shown that in solution DNA charge-transport chemistry generally is sensitive to the stacking characteristics of donor and acceptors and is particularly efficient with well-coupled $\pi$-stacked intercalators. $7,8,19,20,75$

The requisite features of the redox donor and acceptor have not been specifically addressed for DNA-mediated electrochemical charge-transport reactions. Here, we explore the characteristics of the donor/acceptor partners required for efficient DNA-mediated charge transport on DNA-modified surfaces. We focus on coupling to the $\pi$-stack by intercalation and demonstrate that for the DNA-mediated reaction intercalative binding is essential (Figure 1).

\section{Experimental Section}

Materials. Unless otherwise indicated, all reagents and solvents were purchased in their highest available purity and used without further purification. All DNA synthesis reagents were obtained from Glen Research. Millipore MilliQ (18 M $\Omega$ 

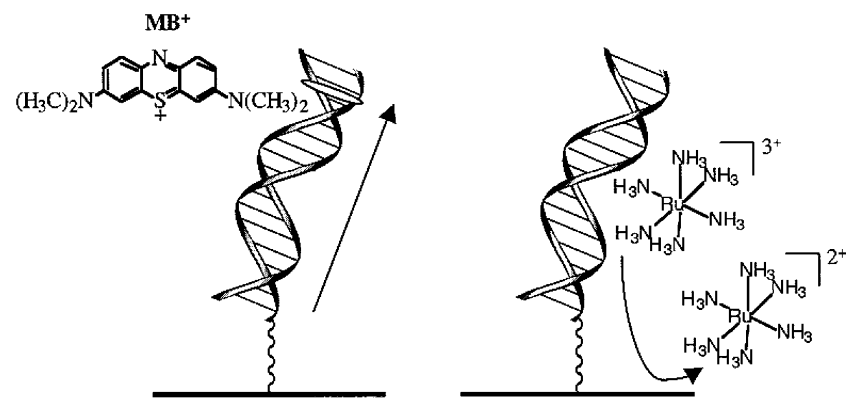

Figure 1. Schematic illustration of $\mathrm{MB}^{+}$(left) and $\mathrm{Ru}\left(\mathrm{NH}_{3}\right)_{6}{ }^{3+}$ (right) bound to an electrode modified with DNA. Likely modes of binding, intercalation for $\mathrm{MB}^{+}$and groove binding for $\mathrm{Ru}\left(\mathrm{NH}_{3}\right)_{6}{ }^{3+}$, and likely paths of electrochemical reduction are indicated. The DNA helices are shown in an upright orientation because previous studies were consistent with this orientation in the presence of the applied potential required for reduction of these DNA-binding molecules..$^{53}$

$\mathrm{cm})$ water was used in all experiments. All plasticware was purchased DNase-, RNase-, and metal-free (Sorenson Bioscience, Inc.)

Preparation of DNA-Modified Surfaces. Thiol-modified single-stranded oligonucleotides were prepared as previously described. ${ }^{52-59}$ After HPLC purification, the thiol-modified single strand was hybridized with its unmodified complement by combining equimolar amounts of each strand (in $5 \mathrm{mM}$ phosphate, $50 \mathrm{mM} \mathrm{NaCl}$ buffer, $\mathrm{pH}$ 7) for a final solution of $0.1 \mathrm{mM}$ duplex. Just before deposition on the gold surfaces, $0.1 \mathrm{M} \mathrm{MgCl}_{2}$ was added to each sample. These duplexes $(0.1$ $\mathrm{mM}$ ) were then deposited on polycrystalline gold electrodes for 12-24 h, thoroughly rinsed with buffer, and used for electrochemical experiments. These surfaces have been characterized by cyclic voltammetry, ellipsometry radiolabeling of the duplexes, and atomic force microscopy (AFM). ${ }^{52,53,57} \mathrm{We}$ have found the DNA films to be densely packed monolayers with the DNA helical axis oriented in an upright position at approximately $45^{\circ}$ with respect to the gold surface. ${ }^{53}$

Electrochemical Measurements. Cyclic voltammetry was carried out anaerobically (bubbling argon) on $0.02 \mathrm{~cm}^{2}$ gold electrodes using a Bioanalytical Systems (BAS) model CV-50W electrochemical analyzer. Buffer and electrolyte conditions were generally $5 \mathrm{mM}$ sodium phosphate buffer containing $50 \mathrm{mM}$ $\mathrm{NaCl}, \mathrm{pH} \mathrm{7,} \mathrm{ambient} \mathrm{temperature,} \mathrm{although} \mathrm{in} \mathrm{certain} \mathrm{experi-}$ ments the ionic strength was controlled with increasing amounts of $\mathrm{Cl}^{-}$(starting from $0 \mathrm{mM} \mathrm{Cl}^{-}$). A normal three-electrode configuration consisting of a modified gold-disk working electrode, a saturated calomel reference electrode (SCE, Fisher Scientific), and a platinum wire auxiliary electrode was used. A modified Luggin capillary separated the working compartment of the electrochemical cell from the reference compartment. Potentials are reported versus SCE.

Passivation of the Electrode Surface by Electropolymerization of 2-Naphthol. After self-assembly, DNA-modified electrodes were rinsed and then immersed in a $100 \mathrm{mM}$ solution of 2-naphthol in $50 \%$ acetonitrile/50\% buffer $(5 \mathrm{mM}$ phosphate, $50 \mathrm{mM} \mathrm{NaCl}, \mathrm{pH}$ 7). 2-Naphthol was then electropolymerized onto the electrode surface by cycling the potential from 0 to $600 \mathrm{mV}$ for several minutes until the cyclic voltammogram was flat. This procedure was then repeated, cycling from 0 to 700 $\mathrm{mV}$. Following this electropolymerization, the electrodes were thoroughly rinsed in $50 \%$ acetonitrile/50\% buffer and then $100 \%$ buffer before use in voltammetry studies.

Synthesis and Characterization of Modified Methylene Blue (MB')-5'-DNA. The synthesis of modified methylene blue, $\mathrm{MB}^{+}\left(\mathrm{MB}^{\prime}=3-[N\right.$-(4-ethoxycarbonylbutyl)- $N$-methylamino $]-$ 7-dimethylaminophenazathionium chloride), was accomplished according to published literature procedures. ${ }^{76} \mathrm{MB}^{+}$refers to unmodified $\mathrm{MB}^{+}$, while $\mathrm{MB}^{\prime}$ refers to modified $\mathrm{MB}^{+}$and $\mathrm{MB}^{\prime}-$ DNA refers to $\mathrm{MB}^{\prime}$ that has been coupled to DNA. $\mathrm{MB}^{\prime}$ was coupled to DNA as follows. This synthesis was accomplished in the dark and in a rigorously deoxygenated atmosphere. $\mathrm{MB}^{\prime}$ (4.71 mmol) was mixed with 0 -( $N$-succinimidyl)- $N, N, N^{\prime}, N^{\prime}$ tetramethyluronium tetrafluoroborate (TSTU, $1 \mathrm{mg}$ ) and diisopropylethylamine $(1 \mu \mathrm{L})$ in dimethyl formamide. The resulting solution was kept at room temperature (RT) for $10 \mathrm{~min}$ to activate the $\mathrm{MB}^{\prime}$ acid to the $N$-succinimidyl form (MB'-NHS). This reaction was monitored by thin-layer chromatography in a methanol chamber.

$\mathrm{NH}_{2}-5^{\prime}$-DNA is made according to published protocol. ${ }^{52-59}$ Oligonucleotides (5'-AGTACAGTCATCGCG-3') are synthesized by standard phosphoramidite chemistry on a controlled pore glass resin. While still attached to the resin, the $5^{\prime}-\mathrm{OH}$ terminus of the DNA strand is treated in succession with carbonyldiimidazole and 1,6-diaminohexane, cleaved from the resin, and purified using HPLC. After activation of $\mathrm{MB}^{\prime}$, aminomodified DNA ( $\mathrm{NH}_{2}-5^{\prime}$-DNA, $70 \mathrm{nmol}$ in $100 \mathrm{mM}$ phosphate) was added to the $\mathrm{MB}^{\prime}$-NHS solution (final solution 3:1 DMF/ $\mathrm{H}_{2} \mathrm{O}$ ), and the vessel was shaken gently. The reaction proceeded to completion in approximately $15 \mathrm{~min}$ at ambient temperature. The final product was purified by reversed-phase HPLC using an acetonitrile and ammonium acetate solvent system. $\mathrm{MB}^{\prime}-5^{\prime}$ DNA was characterized by mass spectrometry, electronic spectroscopy, HPLC, and electrochemistry. The UV-vis absorption profiles are exactly the same in the visible region (absorption maxima at 609 and $668 \mathrm{~nm}, \epsilon_{668}=81600 \mathrm{M}^{-1}$ $\mathrm{cm}^{-1}$ ) for $\mathrm{MB}^{+}-$and $\mathrm{MB}^{\prime}-5^{\prime}$-DNA (the $\mathrm{MB}^{\prime}$-DNA conjugate also had absorption at $260 \mathrm{~nm}$, characteristic of the presence of DNA), yet a change in HPLC retention time indicates the presence of the functional carboxylic acid side chain. A mass of 5112 was found by MALDI-TOF mass spectrometry, corresponding to the sequence $3^{\prime}$-TCATGTCAGTAGCGC-5'$\mathrm{MB}^{\prime}$.

\section{Results}

Ionic Strength Dependence of $\mathrm{MB}^{+}$and $\mathrm{Ru}\left(\mathrm{NH}_{3}\right)_{6}{ }^{3+}$ Binding at DNA-Modified Electrodes. In our efforts to assess the parameters affecting electrochemical charge-transport reactions at DNA-modified surfaces, in particular the effect of coupling to the DNA $\pi$-stack by intercalation, we examined the effect of ionic strength on the reduction potential of $\mathrm{MB}^{+}$ and $\mathrm{Ru}\left(\mathrm{NH}_{3}\right)_{6}{ }^{3+}$ at a DNA-modified electrode. These experiments provide a means of varying DNA-binding characteristics and affinity of the redox probe and allow us to begin to delineate how intercalation versus electrostatic binding to DNA affect the electrochemistry on DNA films. Methylene blue $\left(\mathrm{MB}^{+}\right)$ binds readily to DNA-modified surfaces by intercalation with an association constant of $3.8(5) \times 10^{6} \mathrm{M}^{-1}$ (5 mM phosphate, $50 \mathrm{mM} \mathrm{NaCl}$ buffer, $\mathrm{pH} 7)$ and undergoes a reversible reduction at $-250 \mathrm{mV}$ vs SCE. ${ }^{52} \mathrm{Ru}\left(\mathrm{NH}_{3}\right)_{6}{ }^{3+}$ binds in the groove of duplex DNA, ${ }^{77,78}$ is reduced at approximately the same potential as $\mathrm{MB}^{+}$, and associates with DNA through electrostatic and hydrogen-bonding interactions. Tarlov and co-workers have exploited these properties in the development of an electrochemical assay to quantify DNA immobilized onto an electrode surface. Because the negatively charged DNA preconcentrates $\mathrm{Ru}\left(\mathrm{NH}_{3}\right)_{6}{ }^{3+}$ at the electrode surface, the integrated $\mathrm{Ru}\left(\mathrm{NH}_{3}\right)_{6}{ }^{3+}$ electrochemical signal reports directly on the number of phosphate groups (and by extension, DNA strands) on the surface. ${ }^{79}$ 
(a)

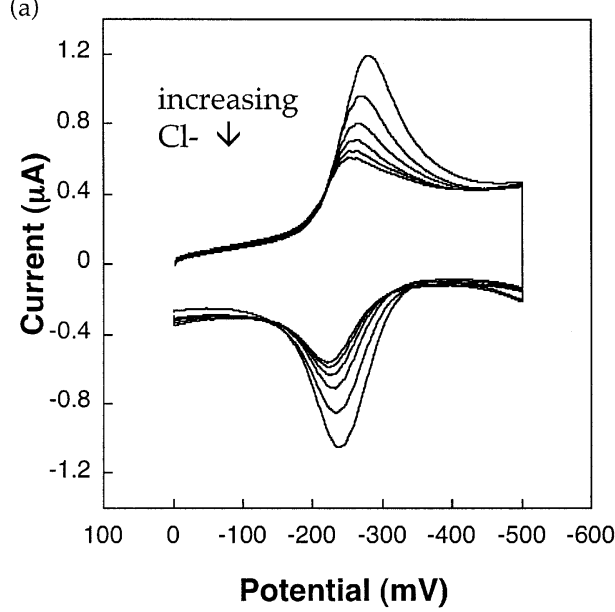

(b)

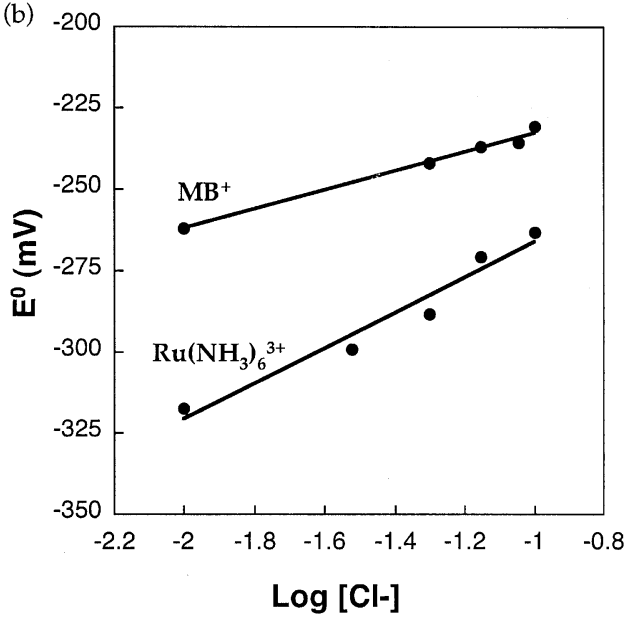

Figure 2. Cyclic voltammetry (a) of $2 \mu \mathrm{M} \mathrm{MB}^{+}$at a gold electrode modified with the thiol terminated sequence SH-5'-AGTACAGTCATCGCG hybridized to its perfect complement in $5 \mathrm{mM}$ phosphate, $\mathrm{pH} \mathrm{7,} \mathrm{buffer}$ at $\mathrm{KCl}$ concentrations from 0 to $500 \mathrm{mM}$ and (b) plots of the observed potential from cyclic voltammetry experiments for an electrode identical to that described in panel a, as well as the cyclic voltammetry of $28 \mu \mathrm{M}$ $\mathrm{Ru}\left(\mathrm{NH}_{3}\right)_{6}{ }^{3+}$ at an electrode identical that to described in panel a at $\mathrm{KCl}$ concentrations from 10 to $100 \mathrm{mM}$. Linear plots are obtained and the slopes are indicative of $2 \mathrm{e}^{-} / 1 \mathrm{H}^{+}$electrochemistry for $\mathrm{MB}^{+}$(slope $=29 \mathrm{mV}$ ) and $1 \mathrm{e}^{-}$chemistry for $\mathrm{Ru}\left(\mathrm{NH}_{3}\right)_{6}{ }^{3+}($ slope $=55 \mathrm{mV})$ bound to $\mathrm{DNA}$. Voltammograms were obtained with scan rate $(v)=50 \mathrm{mV} / \mathrm{s}$ and electrode area $(A)=0.02 \mathrm{~cm}^{2}$.

Gold electrodes modified with the duplex SH-5'-AGTACAGTCATCGCG-3' were fabricated and used in cyclic voltammetry experiments with either $2 \mu \mathrm{M} \mathrm{MB} \mathrm{MB}^{+}$or $28 \mu \mathrm{M}$ $\mathrm{Ru}\left(\mathrm{NH}_{3}\right)_{6}{ }^{3+} . \mathrm{KCl}(0-100 \mathrm{mM})$ was then titrated into the

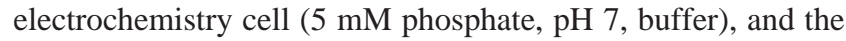
cyclic voltammogram was recorded as a function of ionic strength. As the ionic strength is increased, the polyanionic DNA excludes chloride from the surface. By analogy to other ionselective polyelectrolyte film coatings, the apparent formal potential of a molecule bound within the DNA monolayer is therefore expected to shift as a function of $\mathrm{KCl}$ concentration. ${ }^{80}$

Figure $2 \mathrm{a}$ shows the cyclic voltammograms for $\mathrm{MB}^{+}$bound to a DNA-modified electrode in the presence of varying concentrations of $\mathrm{KCl}$. As seen previously, ${ }^{52}$ plots of both the cathodic and anodic peak currents are linear with scan rate, indicating that the $\mathrm{MB}$ is bound to the surface (indeed, the currents are orders of magnitude larger than what would be observed for freely diffusing $\mathrm{MB}$ at a concentration of $2 \mu \mathrm{M}$ ). This is true for all concentrations of $\mathrm{KCl}$ investigated. Integrating the background-subtracted voltammogram recorded before addition of $\mathrm{KCl}$ yields a $\mathrm{MB}^{+}$surface coverage of $\sim 50 \mathrm{pmol} /$ $\mathrm{cm}^{2}$, in close agreement with previous work, where surface coverages were also determined through radioactive labeling. ${ }^{52}$ Interestingly, both peak widths and peak splittings are somewhat larger than ideal for a surface-bound $2 \mathrm{e}^{-}$Nernstian response, reaching limiting values at slow scan rates $(v=5 \mathrm{mV} / \mathrm{s})$ of $\sim 60$ (20) and $15(10) \mathrm{mV}$, respectively (pH 7). Similar broadenings have been observed for other surface-bound species and attributed either to distributions in redox potentials and heterogeneous electron-transfer rate constants originating from slight inhomogeneities within the film ${ }^{81}$ or to a breakdown in the cooperative nature of the $2 \mathrm{e}^{-}$response within the film or both.

Figure $2 \mathrm{~b}$ shows the effect of added chloride on the reduction potentials of $\mathrm{MB}^{+}$and $\mathrm{Ru}\left(\mathrm{NH}_{3}\right)_{6}{ }^{3+}$ bound to DNA. Linear plots are obtained and the respective slopes of 29 and $55 \mathrm{mV}$ are consistent with a $2 \mathrm{e}^{-} / 1 \mathrm{H}^{+}$response for $\mathrm{MB}^{+}$and a simple $1 \mathrm{e}^{-}$ response for $\mathrm{Ru}\left(\mathrm{NH}_{3}\right)_{6}{ }^{3+} .{ }^{82}$ The observed potential shifts are fully reversible with $\mathrm{KCl}$ concentration, and similar experiments in which the ionic strength was controlled with potassium nitrate gave identical results (data not shown). Thus these data are explained by differences in the redox chemistry of $\mathrm{MB}^{+}$and
$\mathrm{Ru}\left(\mathrm{NH}_{3}\right)_{6}{ }^{3+}$ at varying ionic strength and not interactions of $\mathrm{Cl}^{-}$with the gold surface (e.g., absorption of $\mathrm{Cl}^{-}$onto $\mathrm{Au}$ ).

It is noteworthy that, in addition to the potential shift, an increase in the ionic strength decreases the number of molecules that are reduced, as indicated by lower currents in the cyclic voltammograms (shown for $\mathrm{MB}^{+}$, Figure 2a). High salt concentrations effectively inhibit the DNA binding of both electrostatically bound ions and DNA intercalators. ${ }^{83}$ Thus, it is apparent that efficient charge transport at DNA-modified surfaces takes place only when the molecules are bound tightly to DNA, either by intercalation $\left(\mathrm{MB}^{+}\right)$or by groove-binding $\left(\mathrm{Ru}\left(\mathrm{NH}_{3}\right)_{6}{ }^{3+}\right)$. It should be noted also in comparing the intensities of reduced and oxidized species that both for $\mathrm{MB}^{+}$ and $\mathrm{Ru}\left(\mathrm{NH}_{3}\right)_{6}{ }^{3+}$ the more highly charged DNA-binding moiety is bound more appreciably, consistent with the higher affinity for the higher charged cationic species to the DNA polyanion (see also Figure 3). This experiment does not reveal whether the charge transport takes place through the $\pi$-stacked base pairs of DNA or by some other fashion, but these data do support the assertion that the observed electrochemistry at DNAmodified electrodes is most efficient when the redox probe is bound to the DNA film.

Electrode Passivation by Polymerization of 2-Naphthol. Having established DNA binding as a critical aspect for efficient reduction at DNA-modified surfaces, we next sought to determine differences in the charge-transport characteristics associated with DNA-binding mode, intercalation $\left(\mathrm{MB}^{+}\right)$versus groove binding $\left(\mathrm{Ru}\left(\mathrm{NH}_{3}\right)_{6}{ }^{3+}\right)$. We considered that reduction of $\mathrm{Ru}\left(\mathrm{NH}_{3}\right)_{6}{ }^{3+}$ might proceed through the facilitated diffusion of the ruthenium complex along the grooves of the immobilized helices so as to contact the gold surface directly; because of the lack of ability to intercalate, we would propose that the redox reaction could not occur through a charge-transport process mediated by the base pair stack.

To test this proposal and to distinguish this path from those paths available to the intercalating $\mathrm{MB}^{+}$, we performed studies in which the bare Au on the DNA-modified electrode surface was passivated with electropolymerized 2-naphthol. ${ }^{84,85}$ Importantly, although the DNA on these electrode surfaces is tightly packed, the diameter of DNA is approximately an order of magnitude greater than that of the linker; thus, there is 

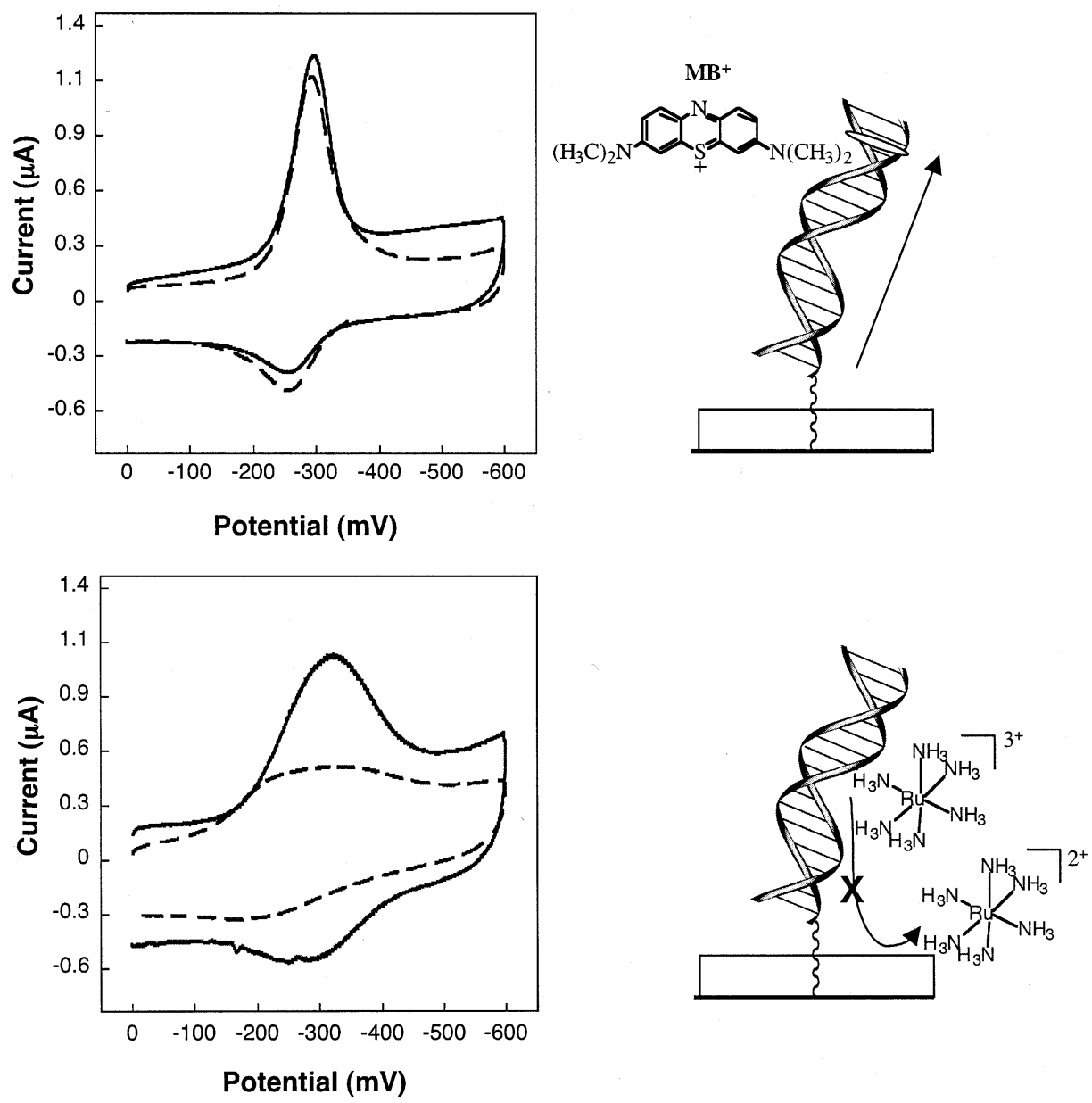

Figure 3. Cyclic voltammetry of $2 \mu \mathrm{M} \mathrm{MB}^{+}$(top) and $28 \mu \mathrm{M} \mathrm{Ru}\left(\mathrm{NH}_{3}\right)_{6}{ }^{3+}$ (bottom) at a gold electrode modified with the thiol-terminated duplex SH-5'-AGTACAGTCATCGCG in $5 \mathrm{mM}$ phosphate, $50 \mathrm{mM} \mathrm{NaCl}, \mathrm{pH}$ 7, before (solid line) and after (dotted line) electrode passivation with polymerized 2-naphthol. The reduction of $\mathrm{MB}^{+}$, which binds to DNA by intercalation, is not affected by surface passivation; however, the reduction of $\mathrm{Ru}\left(\mathrm{NH}_{3}\right)_{6}{ }^{3+}$, a groove binder, is strongly inhibited by electropolymerized 2-naphthol. Voltammograms were obtained with scan rate $(v)=50$ $\mathrm{mV} / \mathrm{s}$ and electrode area $(A)=0.02 \mathrm{~cm}^{2}$. When the electrode surface between duplexes is passivated with 2-naphthol, only those molecules that can be electrochemically accessed by charge transport through the DNA base stack can be reduced.

presumably a significant amount of bare Au beneath the DNA film between the alkanethiol chains linking the DNA to the surface. Thus at an electrode surface passivated with this polymer, facilitated diffusion along the DNA duplex above the passivated surface would still be available, but electrochemical reduction resulting from direct contact of the acceptor with the electrode surface would be blocked (Figure 3). Electrochemical reductions resulting from charge injection into and transport through DNA would not, however, be expected to be affected by coating the available gold surface area with polymerized 2-naphthol, as long as the surface passivation does not interfere with the structure of the DNA duplex.

Gold surfaces modified with the duplex SH-5'-AGTACAGTCATCGCG-3' were fabricated as described previously. ${ }^{52-59}$ Cyclic voltammograms of either $2 \mu \mathrm{M} \mathrm{MB}^{+}$or $28 \mu \mathrm{M} \mathrm{Ru}-$ $\left(\mathrm{NH}_{3}\right)_{6}{ }^{3+}$ were recorded at these DNA-modified electrodes. Separate DNA-modified electrodes were then passivated with electropolymerized 2-naphthol, and then cyclic voltammograms of $2 \mu \mathrm{M} \mathrm{MB}^{+}$and $28 \mu \mathrm{M} \mathrm{Ru}\left(\mathrm{NH}_{3}\right)_{6}{ }^{3+}$ were recorded in parallel.

Figure 3 illustrates the electrochemistry of $\mathrm{MB}^{+}$and $\mathrm{Ru}\left(\mathrm{NH}_{3}\right)_{6}{ }^{3+}$ bound to a DNA-modified electrode with and without surface passivation. While treatment with polymerized 2-naphthol has only a small effect on the reduction of $\mathrm{MB}^{+}$(a $\sim 3 \%$ reduction in the signal), the effect on the reduction of $\mathrm{Ru}\left(\mathrm{NH}_{3}\right)_{6}{ }^{3+}$ is profound (with $>70 \%$ loss in the signal). Although the effects of 2-naphthol polymerization on the film morphology are difficult to assess, the dramatic difference between the electrochemical responses of $\mathrm{MB}^{+}$and $\mathrm{Ru}\left(\mathrm{NH}_{3}\right)_{6}{ }^{3+}$ suggests that reduction of these two molecules at DNA-modified surfaces proceeds by fundamentally different pathways. Indeed, the electrochemical results are consistent with a model in which the reduction of $\mathrm{MB}^{+}$takes place by charge transport through the DNA helix and not by direct contact with the electrode surface. This base-stack-mediated reaction is only available to reactants intercalated into the double helix.

Electrochemistry and Ionic Strength Dependence of Covalently Bound $\mathbf{M B}^{+}$. To further explore the requirement of intercalation for efficient DNA-mediated charge transport at DNA-modified surfaces, we also sought to compare directly the effects on DNA electrochemistry of covalent association through $\sigma$-bonding versus noncovalent $\pi$-stacking. DNA films were constructed containing modified $\mathrm{MB}^{+}\left(\mathrm{MB}^{\prime}\right)$ covalently tethered to the $5^{\prime}$ end of the oligonucleotide strand that did not contain the alkane thiol ( $\mathrm{MB}^{\prime}-5^{\prime}$-DNA). Given the small length of the tether, $\mathrm{MB}^{\prime}$ was constrained to intercalate near the top of the DNA film. HPLC, mass spectrometry, and UV-visible spectroscopy all supported the construction of these modified oligomers.

At a gold surface modified with thiol-derivatized $\mathrm{SH}-5^{\prime}$ AGTACAGTCATCGCG-3' hybridized to 3'-TCATGTCAGTAGCGC-5'-MB' (MB'-DNA-SH), an electrochemical signal attributable to $\mathrm{MB}^{\prime}$ is observed (Figure 4). The potential and 

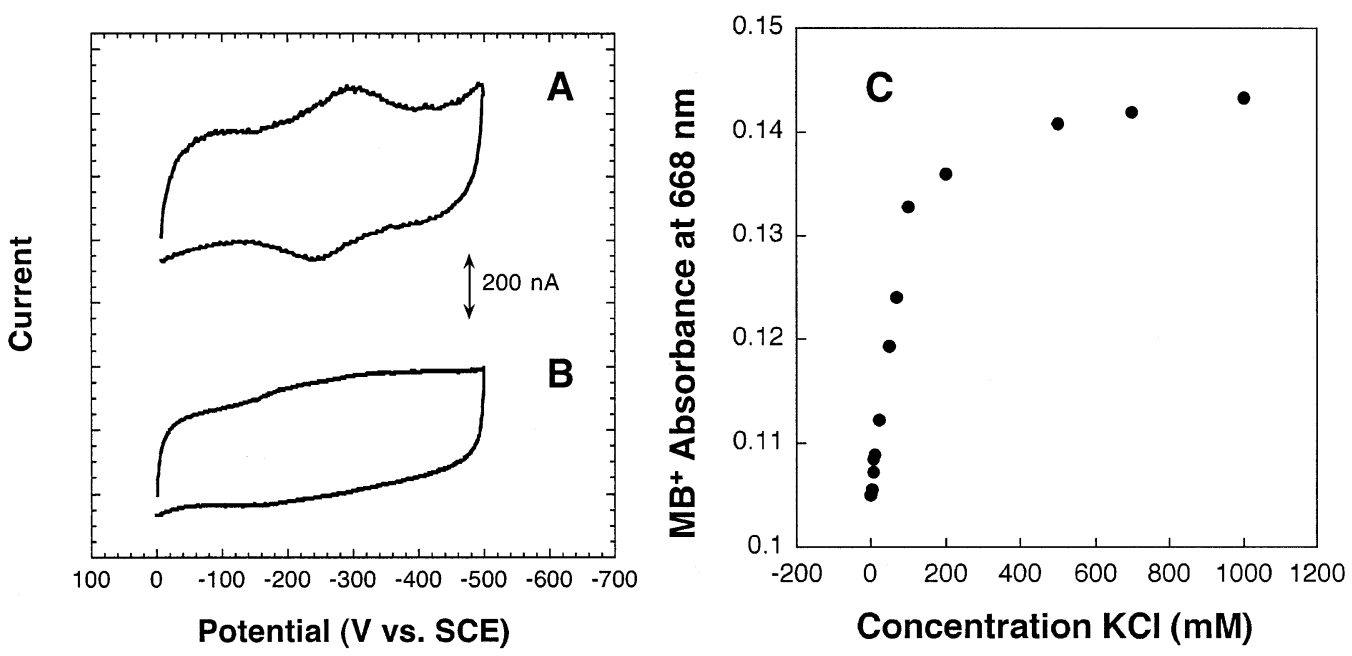

Figure 4. Cyclic voltammetry at a gold electrode modified with the thiol-terminated sequence SH-5'-AGTACAGTCATCGCG hybridized to its complement modified with $\mathrm{MB}^{\prime}$ in $5 \mathrm{mM}$ phosphate, $50 \mathrm{mM} \mathrm{NaCl}$, pH 7, buffer with either (A) $0 \mathrm{mM} \mathrm{MgCl}_{2}$ or (B) $500 \mathrm{mM} \mathrm{MgCl} 2$ added. At high ionic strength, $\mathrm{MB}^{\prime}$ intercalation to DNA is inhibited, resulting in no reduction of $\mathrm{MB}^{\prime}$, despite the fact that $\mathrm{MB}^{\prime}$ remains covalently attached to the electrode surface. Voltammograms were obtained with scan rate $(v)=50 \mathrm{mV} / \mathrm{s}$ and electrode area $(A)=0.02 \mathrm{~cm}^{2}$. Panel C shows a plot of UV-visible absorbance at $668 \mathrm{~nm}$ for a solution containing $2 \mu \mathrm{M} \mathrm{MB}^{+}$and $2 \mu \mathrm{M} \mathrm{5}$-AGTACAGTCATCGCG hybridized to its complement in 5 $\mathrm{mM}$ phosphate, $\mathrm{pH} 7$, buffer and titrated with $\mathrm{KCl}$ concentrations from 0 to $1000 \mathrm{mM}$. As ionic strength is increased, $\mathrm{MB}^{+}$dissociates from $\mathrm{DNA}$.

peak splittings qualitatively agree with those seen for $\mathrm{MB}^{+}$ bound noncovalently to the DNA-modified electrodes, and here $\mathrm{MB}^{\prime}$ is clearly bound to the electrode surface. Notably, the integrated wave is consistently found to be only $\sim 60 \%$ as large as those typically seen for $\mathrm{MB}^{+}$noncovalently bound under the same conditions. This yields a surface coverage of electroactive $\mathrm{MB}^{\prime}$ of $\sim 30 \mathrm{pmol} / \mathrm{cm}^{2}$. These SH-DNA-MB' films completely block ferrocyanide oxidation at the electrode surface, however, just as do films of the SH-DNA analogues, where the surface coverages are found to be $\sim 50 \mathrm{pmol} / \mathrm{cm}^{2}$ through integration of $\mathrm{MB}^{+}$signals or radioactive labeling. Spectroscopic studies of similar duplex DNA-MB' conjugates have shown that a distribution of intercalated and unbound (but tethered) $\mathrm{MB}^{\prime}$ exists in solution, so the smaller electrochemical signals seen here may therefore reflect a population of $\mathrm{MB}^{\prime}$ that remains unintercalated or poorly coupled into the DNA film.

As demonstrated earlier (vide supra), high salt concentrations can inhibit DNA binding by the intercalator. We therefore measured the cyclic voltammetry of $\mathrm{MB}^{+}$bound to DNAmodified electrodes and the UV-visible spectroscopy of $\mathrm{MB}^{+}$ binding to DNA in solution in the presence of high salt concentrations to investigate whether the covalently bound $\mathrm{MB}^{\prime}$ would effectively intercalate into DNA under these conditions and whether it would still be reduced by DNA-mediated electrochemistry. Upon addition of $500 \mathrm{mM} \mathrm{MgCl} 2$ to covalently bound MB'-DNA-SH films, the electrochemical signal for $\mathrm{MB}^{\prime}$ is lost (Figure 4). Thus, with increased ionic strength, $\mathrm{MB}^{\prime}$ is not intercalated, and without intercalation, the charge-transport reaction is prohibited (Figure 5). Upon dilution of the $\mathrm{MgCl}_{2}$ with $5 \mathrm{mM}$ phosphate, $50 \mathrm{mM} \mathrm{NaCl}(\mathrm{pH}$ 7) buffer, however, the $\mathrm{MB}^{\prime}$ electrochemical signal returns, indicating that $\mathrm{MB}^{\prime}$ once again intercalates into the DNA film and charge-transport proceeds. Similarly, when increasing concentrations of $\mathrm{KCl}$ were titrated into a solution of $2 \mu \mathrm{M} \mathrm{MB}^{+}$and $2 \mu \mathrm{M}$ duplex $\left(5^{\prime}\right.$ AGTACAGTCATCGCG-3'), the absorption at $668 \mathrm{~nm}$ increased with increasing ionic contribution, indicating that intercalation is inhibited at high salt concentrations (Figure 4b).

This experiment provides strong support for the long-range reduction in DNA films of DNA-bound species, but only when intercalated. Thus the requirement of intercalating reactants for

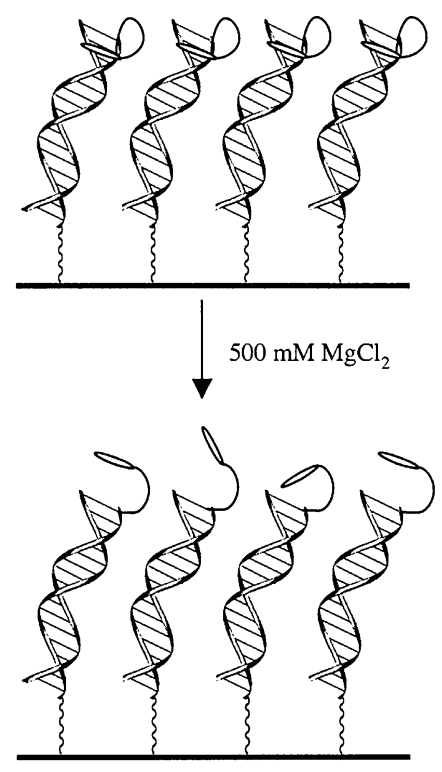

Figure 5. Schematic illustration of $\mathrm{MB}^{\prime}$ intercalation within a DNA monolayer at low and high ionic strength.

efficient long-range charge-transport reactions mediated by the base pair stack at DNA films is emphasized.

\section{Discussion}

Electrochemistry at DNA-modified electrodes can be accomplished effectively with small molecules that bind tightly to DNA. The efficiency of this electrochemistry is strongly affected by features of the redox probe, however. More specifically, molecules that bind DNA by intercalation can undergo redox chemistry on the modified electrodes in a reaction that is mediated by the DNA helix. These ideas are underscored by DNA electrochemistry studies as a function of ionic strength and in studies in which the electrodes, after modification with DNA, are passivated to inhibit direct contact of the DNAbinding molecules with the gold surface. Experiments using an intercalator covalently tethered to the DNA film unequivocally establish intercalation into the stacked base pairs as a requirement for long-range charge transport. 
The electrode surface passivation studies allow us to distinguish redox probes in DNA electrochemistry based upon their binding mode. In the case of $\mathrm{Ru}\left(\mathrm{NH}_{3}\right)_{6}{ }^{3+}$, the DNA film acts as a scaffold for delivery to the gold surface. While the DNA film serves to concentrate the groove-binding molecule near the gold surface, passivation of the surface limits direct contact and therefore turns off the ruthenium hexammine electrochemistry. The DNA film, however, serves a different role in redox reactions of the intercalator within the film. In the case of intercalating $\mathrm{MB}^{+}$, the DNA base pair stack provides a bridge for charge transport. As a consequence, surface passivation has no significant effect on the electrochemistry of methylene blue. With the $\pi$-stacked intercalator, the DNA duplex mediates the reaction.

This critical characteristic of DNA electrochemistry associated with intercalation is demonstrated still more clearly in studies using $\mathrm{MB}^{+}$covalently tethered to the DNA film. In these assemblies, the position of $\mathrm{MB}^{\prime}$ is restricted to the top of the DNA film and whether methylene blue is intercalated or not is controlled by ionic strength. Experimentally, it is observed that despite being covalently attached to the DNA surface and coupled to the DNA through $\sigma$-bonding, when the $\mathrm{MB}^{\prime}$ is not intercalated into the base pairs at high ionic strength its electrochemical reduction does not occur. Indeed, if charge transport involved direct contact between the $\mathrm{MB}^{\prime}$ and gold surface, such direct contact would be facilitated in this disintercalated form at high ionic strength. Interestingly, because an electrochemical signal is observed when $\mathrm{MB}^{\prime}$ is intercalated but not observed at higher salt concentrations when $\mathrm{MB}^{\prime}$ is not intercalated but still attached, this indicates that the rate of electron transfer must be much slower through the aliphatic linker to $\mathrm{MB}^{\prime}$ than through the DNA base pairs to $\pi$-stacked $\mathrm{MB}^{\prime}$. Thus the results here underscore the utility of intercalating probes for DNA electrochemistry. It is noteworthy that particularly effective DNA charge transport has been observed with intercalators also in photophysical studies of DNA charge transport. ${ }^{7,8,19,20,75}$

The proposed path for charge transport is furthermore consistent with our previous electrochemical investigations at DNA-modified surfaces. ${ }^{52-59}$ In these studies, we focused on $\mathrm{MB}^{+52}$ and daunomycin, ${ }^{54,55}$ both intercalators, as redox probes. The electrochemical signals obtained with both probes exhibited a linear correlation between current and scan rate, indicating that the reactive species were strongly bound to the surface. For the noncovalent intercalator, electrochemistry results reflected an intercalator-to-DNA binding stoichiometry of approximately $1: 1$, consistent with the notion that intercalating probes bind predominantly near the solvent-exposed terminus of the DNA film with diffusion into the monolayer being inhibited by tight packing of the DNA helices; hence, the electrochemistry would require primarily a DNA-mediated reaction. We also, however, examined the electrochemical response for DNA films prepared with daunomycin bound as a covalent adduct, where the distance between the daunomycin and the gold surface was systematically varied over a distance range of 15-45 $\AA$. In these studies, too, the effective electrochemical reduction of daunomycin was observed in the DNA films over the full distance range, and the overall rate of electron transfer was not significantly diminished through this distance regime. Here, consistent with the daunomycin study, we observe electron transfer with covalently tethered and intercalated $\mathrm{MB}^{\prime}$ at a distance of $40 \AA$ from the gold surface with the reaction mediated by the base pair stack.

The data presented here, as well as the proposed path for electrochemistry in DNA films, are also in strong agreement with our electrochemistry studies designed to detect single base pair mismatches and other perturbations to the DNA helix intervening between the redox probe and the gold surface. ${ }^{54-56,58,59}$ Mismatches offer only very minor structural changes to a DNA duplex; they are generally stacked and do not significantly distort the sugar-phosphate backbone of DNA, but they do undergo greater dynamical motion than Watson-Crick-paired bases. ${ }^{86-91}$ Thus it follows that charge transport in DNA would be sensitive to the enhanced base stack motions associated with mismatches, provided that the charge-transport pathway involved the extended $\pi$-stack. ${ }^{91}$ Interestingly, solution studies examining charge transport between donor and acceptor molecules bound to DNA or charge transport resulting in oxidation of the DNA molecule itself have also been described as mediated by the base stack of DNA and have shown parallel sensitivities to mismatches and other perturbations in the intervening stack.

Significantly, then, the results here also establish that efficient electrochemical reduction of an intercalator occurs at long range and is $\pi$-stack-mediated. Nonetheless, the detailed mechanism of this DNA-mediated charge transport has not been established. While substantial discussion is ongoing concerning the mechanisms underlying photophysical studies of DNA charge transport, ${ }^{32-49}$ the debate has focused primarily on a mixture of hopping and superexchange mechanisms, hopping being used to explain the shallow distance dependences observed over long range. Unlike photooxidation experiments, which involve highly reactive intermediates (e.g., $\mathrm{Ru}^{3+}$, a typical photooxidant used in DNA charge transport studies, has $E^{\circ} \approx+1.6 \mathrm{~V}$ vs NHE), these electrochemical experiments feature redox probes whose redox potentials are far away from the DNA bridge orbitals (reduction of pyrimidines $\approx-1.1 \mathrm{~V}$, oxidation of purines $\approx$ $+1.3 \mathrm{~V}$ vs NHE). ${ }^{92,93}$ Without a significant change in orbital energetics associated with the DNA stack, a mechanism in which the charge delocalizes onto the DNA molecular orbitals is highly unlikely. It is, however, clear that the charge-transport reaction is quite sensitive to small perturbations in the DNA bridge.

Heller and co-workers have put forth an interesting proposal for the mechanism of charge transport at DNA-modified surfaces. ${ }^{45}$ According to this model, conduction along the axis of DNA in a one-dimensionally ordered DNA film is attributed to the reduced difference between the static and high-frequency longitudinal dielectric constants. They argue that the highfrequency longitudinal polarizability within a DNA-modified surface is raised because of the concerted movement of cations along the axis of DNA when an electric potential is applied and that the static dielectric constant is lowered because of reduced hydration of DNA films relative to that in solution. This change in the dielectric function increases the mobility of electrons in the film and makes DNA a one-dimensional semiconductor. Although the data presented here do not speak directly to this as the mechanism, our results are not inconsistent with the proposal of an increased longitudinal polarizability associated with the DNA bases in the $\pi$-stack. As described, however, this mechanism depends on a collective property of the DNA film. We have observed similar DNA electrochemistry with daunomycin adducts in DNA films at lower density, where perturbations associated with protein binding were measured. ${ }^{58}$ While these studies suggest that the high densities of the film are not a requirement for long-range charge transport in the monolayer, we have not yet examined the DNA electrochemistry systematically as a function of DNA density. We have also observed photooxidation results in solution that are consistent with a high longitudinal polarizability associated with DNA. ${ }^{43}$ 
Ionic conduction through hydration layers around DNA molecules has been ascribed to charge transport in assemblies of DNA. ${ }^{94}$ Our data do not seem to fit this model, however. If the electrochemistry signals that we observe were the result of ionic conduction through water on the outside of DNA, passivation of the electrode surface should shut down this process. However, as we have shown here, intercalators bound in the DNA base stack are still redox active even at an electrode passivated by polymerized 2-naphthol. Furthermore, one might expect that relative access to the hydration layer around DNA would be better under conditions where the redox probe, here $\mathrm{MB}^{\prime}$, is disintercalated by high ionic strength and is thus very close to the DNA backbone but not intercalated into the base stack. However, this is exactly opposite of what we experimentally observe. $\mathrm{MB}^{\prime}$ is only redox active when intercalated into DNA and not when it is forced out of the helix at high ionic strength. Instead intercalation into DNA seems to be the critical feature of DNA charge-transport electrochemistry. It is possible that the DNA intercalators serve in part as a dopant in these experiments, making DNA an effective semiconductor. Certainly these data now warrant the attention of theorists to provide mechanistic insights that can be experimentally tested.

In summary, these data demonstrate that efficient electrochemistry in DNA films is not dependent on direct contact with the gold surface but requires intercalation of the redox probe. Together with previous studies of DNA intercalators bound to DNA films, these data indicate that this electrochemistry is mediated by the $\pi$-stack of DNA. DNA intercalators, which are themselves coupled into the $\pi$-stack of DNA and thus provide electronic access to the base pairs, represent critical elements for effective DNA electrochemistry at long range, just as they represent particularly effective donors and acceptors in photophysical studies of DNA charge transport. Thus electrochemistry experiments on DNA films using intercalators as redox probes constitute another class of experiments demonstrating long-range DNA charge transport. Mechanistic theories to explain DNA charge transport must also take these experiments into account.

Acknowledgment. We are grateful to the National Institutes of Health (Grant GM61077) for their financial support of this research. In addition, we thank the Parsons Foundation for fellowship support (E.M.B.)

\section{References and Notes}

415.

(1) Eley, D. D.; Spivey, D. I. Trans. Faraday Soc. 1962, 58, 411-

(2) Snart, R. S. Biopolymers 1968, 6, 293-297.

(3) Okahata, Y.; Kobayashi, T.; Tanaka, K.; Shimomura, M. J. Am. Chem. Soc. 1998, 120, 6165-6166.

(4) Fink, H. W.; Schonenberger, C. Nature 1999, 398, 407-410.

(5) Porath, D.; Bezryadin, A.; de Vries, S.; Dekker, C. Nature 2000. 403, 635-638.

(6) Kasumov, A. Y.; Kociak, M.; Gueron, S.; Reulet, B.; Volkov, V. T.; Klinov, D. V.; Bouchiat, H. Science 2001, 291, 280-282.

(7) Murphy, C. J.; Arkin, M. R.; Jenkins, Y.; Ghatlia, N. D.; Turro, N. J.; Barton, J. K. Science 1993, 262, 1025-1029.

(8) Kelley, S. O.; Holmlin, R. E.; Stemp, E. D. A.; Barton, J. K. J. Am. Chem. Soc. 1997, 119, 9861-9870.

(9) Lewis, F.; Wu, T.; Zhang, Y.; Letsinger, R.; Greenfield, S.; Wasielewski, M. Science 1997, 277, 673-676.

(10) Meade, T. J.; Kayyem, J. F. Angew. Chem., Int. Ed. Engl. 1995, $34,352-354$.

(11) Nunez, M. E.; Hall, D. B.; Barton, J. K. Chem. Biol. 1999, 6, 8597.

(12) Ly, D.; Sanii, L.; Schuster, G. B. J. Am. Chem. Soc. 1999, 121, 9400-9410. $49-72$.
(14) Hall, D. B.; Holmlin, R. E.; Barton, J. K. Nature 1996, 382, 731735.

(15) Arkin, M. R.; Stemp, E. D. A.; Coates-Pulver, S.; Barton, J. K. Chem. Biol. 1997, 4, 389-400.

(16) Hall, D. B.; Kelley, S. O.; Barton, J. K. Biochemistry 1998, 37, $15933-15940$.

(17) Saito, I.; Nakamura, T.; Nakatani, K.; Yoshioka, Y.; Yamaguchi, K.; Sugiyama, H. J. Am. Chem. Soc. 1998, 120, 12686-12687.

(18) Meggers, E.; Kusch, D.; Spichty, M.; Wille, U.; Giese, B. Chem Int. Ed. Engl. 1998, 37, 460-462.

(19) Kelley, S. O.; Barton, J. K. Chem. Biol. 1998, 5, 413-425

(20) Kelley, S. O.; Barton, J. K. Science 1999, 283, 375-381.

(21) Hall, D. B.; Barton, J. K. J. Am. Chem. Soc. 1997, 119, 5045 481 .

(22) Odom, D. T.; Dill, E. A.; Barton, J. K. Chem. Biol. 2000, 7, 475-

(23) Rajski, S. R.; Kumar, S.; Roberts, R. J.; Barton, J. K. J. Am. Chem. Soc. 1999, 121, 5615-5616.

(24) Rajski, S. R.; Barton, J. K. Biochemistry 2001, 40, 5556-5564.

(25) Odom, D. T.; Barton, J. K. Biochemistry 2001, 40, 8727-8737.

(26) Sartor, V.; Henderson, P. T.; Schuster, G. B. J. Am. Chem. Soc.

1999, 121, 11027-11033.

(27) Nunez, M. E.; Noyes, K. T.; Gianolio, D. A.; McLaughlin, L. W.; Barton, J. K. Biochemistry 2000, 39, 6190-6199.

(28) Kan, Y. Z.; Schuster, G. B. J. Am. Chem. Soc. 1999, 121, 1160711614.

(29) Gasper, S. M.; Schuster, G. B. J. Am. Chem. Soc. 1997, 119, $12762-12771$.

(30) Stemp, E. D. A.; Holmlin, R. E.; Barton, J. K. Inorg. Chim. Acta 2000, 297, 88-97.

(31) Odom, D. T.; Dill, E. A.; Barton, J. K. Nucleic Acids Res. 2001, 29, 2026-2033.

(32) Wan, C.; Fiebig, T.; Kelley, S. O.; Treadway, C. R.; Barton, J. K.; Zewail, A. H. Proc. Natl. Acad. Sci. U.S.A. 1999, 96, 6014-6019.

(33) Wan, C.; Fiebig, T.; Schiemann, O.; Barton, J. K.; Zewail, A. H. Proc. Natl. Acad. Sci. U.S.A. 2000, 97, 14052-14055.

(34) Hess, S.; Gotz, M.; Davis, W. B.; Michel-Beyerle, M. E. J. Am. Chem. Soc. 2001, 123, 10046-10055.

(35) Giese, B. Acc. Chem. Res. 2000, 33, 631-636.

(36) Voityuk, A. A.; Rosch, N.; Bixon, M.; Jortner, J. J. Am. Chem. Soc. 2000 122, 9740-9745.

(37) Berlin, Y. A.; Burin, A. L.; Ratner, M. A. J. Am. Chem. Soc. 2001, $123,260-268$.

(38) Meggers, E.; Michel-Beyerle, M. E.; Giese, B. J. Am. Chem. Soc. 1998, 120, 12950-12955.

(39) Williams, T. T.; Odom, D. T.; Barton, J. K. J. Am. Chem. Soc. 2000, 122, 9048-9049.

(40) Giese, B.; Amaudrut, J.; Kohler, A. K.; Spormann, M.; Wessely, S. Nature 2001, 412, 318-320.

(41) Henderson, P. T.; Jones, D.; Hampikian, G.; Kan, Y.; Schuster, G. B. Proc. Natl. Acad. Sci. U.S.A. 1999, 96, 8353-8358.

(42) Barnett, R. N.; Cleveland, C. L.; Joy, A.; Landman, U.; Schuster, G. B. Science 2001, 294, 567-571.

(43) Williams, T. T.; Barton, J. K. J. Am. Chem. Soc. 2002, 124, 18401841.

(44) DeLumley-Woodyear, T.; Campbell, C. N.; Heller, A. J. Am. Chem. Soc. 1996, 118, 5504-5505.

(45) Hartwich, G.; Caruana, D. J.; de Lumley-Woodyear, T.; Wu, Y. B.; Campbell, C. N.; Heller, A. J. Am. Chem. Soc. 1999, 121, 1080310812.

(46) Marcus, R. A.; Sutin, N. Biochim. Biophys. Acta 1985, 811, 265322.

(47) Bixon, M.; Giese, B.; Wessely, S.; Langenbacher, T.; MichelBeyerle, M. E.; Jortner, J. Proc. Natl. Acad. Sci. U.S.A. 1999, 96, 1171311716.

(48) Lewis, F. D.; Liu, X. Y.; Liu, J. Q.; Hayes, R. T.; Wasielewski, M. R. J. Am. Chem. Soc. 2000, 122, 12037-12038.

(49) Lewis, F. D.; Letsinger, R. L.; Wasielewski, M. R. Acc. Chem. Res. 2001, 34, 159-170.

(50) Nunez, M. E.; Noyes, K. T.; Barton, J. K. Chem. Biol. 2002, 9 , 403-415.

(51) Nunez, M. E.; Holmquist, G. P.; Barton, J. K. Biochemistry 2001, $40,12465-12471$.

(52) Kelley, S. O.; Barton, J. K.; Jackson, N. M.; Hill, M. G. Bioconjugate Chem. 1997, 8, 31-37.

(53) Kelley, S. O.; Barton, J. K.; Jackson, N. M.; McPherson, L. D.; Potter, A. B.; Spain, E. M.; Allen, M. J.; Hill, M. G. Langmuir 1998, 14, $6781-6784$

(54) Kelley, S. O.; Jackson, N. M.; Hill, M. G.; Barton, J. K. Angew. Chem., Int. Ed. 1999, 38, 941-945.

(55) Kelley, S. O.; Boon, E. M.; Barton, J. K.; Jackson, N. M.; Hill, M. G. Nucleic Acids Res. 1999, 27, 4830-4837.

(56) Boon, E. M.; Ceres, D. M.; Drummond, T. G.; Hill, M. G.; Barton, J. K. Nat. Biotechnol. 2000, 18, 1096-1100. 
(57) Boon, E. M.; Barton, J. K.; Sam, M.; Hill, M. G.; Spain, E. M. Langmuir 2001, 17, 5727-5730.

(58) Boon, E. M.; Salas, J. E.; Barton, J. K. Nat. Biotechnol. 2002, 20, $282-286$

(59) Boon, E. M.; Barton, J. K.; Pradeepkumar, P. I.; Isaksson, J.; Petit, C.; Chattopadhyaya, J. Angew. Chem., Int. Ed., in press.

(60) Millan, K. M.; Mikkelsen, S. R. Anal. Chem. 1993, 65, $2317-$ 2323.

(61) Millan, K. M.; Saraullo, A.; Mikkelsen, S. R. Anal. Chem. 1994 $66,2943-2948$

(62) Xu, X. H.; Bard, A. J. J. Am. Chem. Soc. 1995, 117, 2627-2631.

(63) Xu, X. H.; Yang, H. C.; Mallouk, T. E.; Bard, A. J. J. Am. Chem. Soc. 1994, 116, 8386-8387.

(64) Takenaka, S.; Yamashita, K.; Takagi, M.; Kondo, H. Anal. Chem. 2000, 72, 1334-1341.

(65) Johnston, D. H.; Glasgow, K. C.; Thorp, H. H. J. Am. Chem. Soc. 1995, 117, 8933-8938.

(66) Napier, M. E.; Loomis, C. R.; Sistare, M. F.; Kim, J.; Eckhardt, A.

E.; Thorp, H. H. Bioconjugate Chem. 1997, 8, 906-913.

(67) Ropp, P. A.; Thorp, H. H. Chem. Biol. 1999, 6, 599-605.

(68) Creager, S.; Yu, C. J.; Bamdad, C.; O’Connor, S.; MacLean, T.; Lam, E.; Chong, Y.; Olsen, G. T.; Luo, J.; Gozin, M.; Kayyem, J. F. J. Am. Chem. Soc. 1999, 121, 1059-1064.

(69) Wang, J.; Palecek, E.; Nielsen, P. E.; Rivas, G.; Cai, X. H.; Shiraishi, H.; Dontha, N.; Luo, D. B.; Farias, P. A. M. J. Am. Chem. Soc. 1996, 118, 7667-7670.

(70) Wang, J.; Cai, X. H.; Rivas, G.; Shiraishi, H.; Farias, P. A. M.; Dontha, N. Anal. Chem. 1996, 68, 2629-2634.

(71) Palanti, S.; Marrazza, G.; Mascini, M. Anal. Lett. 1996, 29, 23092331.

(72) Liu, S. H.; Ye, J. N.; He, P. G.; Fang, Y. H. Anal. Chim. Acta 1996, 335, 239-243.

(73) Palecek, E.; Miroslav, F. Anal. Chem. 2001, 73, 74A-83A

(74) (a) Anderson, J. L.; Bowden, E. F.; Pickup, P. G. Anal. Chem. 1996, 68, 379R-444R. (b) Saveant, J. M. Acc. Chem. Res. 1980, 13, 323.

(75) Delaney, S.; Pascaly, M.; Bhattacharya, P. K.; Han, K.; Barton, J. K. Inorg. Chem. 2002, 41, 1966-1974.

(76) Motsenbocker, M. A.; Masuya, H.; Miyawaki, T.; Shimadzu, H. Eur. Pat. Appl. 0510668 A2, 1992.
(77) Karthe, P.; Gautham, N. Acta Crystallogr. 1998, 54, 501-509.

(78) Ho, P. S.; Frederick, C. A.; Saal, D.; Wang, A. H.-J.; Rich, A. J. Biomol. Struct. Dyn. 1987, 4, 521-534.

(79) Steel, A. B.; Herne, T. M.; Tarlov, M. J. Anal. Chem. 1998, 70, 4670-4677.

(80) Naegeli, R.; Redepenning, J.; Anson, F. C. J. Phys. Chem. 1986 $90,6227$.

(81) Rowe, G. K.; Carter, M. T.; Richardson, J. N.; Murray, R. W. Langmuir 1995, 11, 1797-1806.

(82) Further evidence for a $2 \mathrm{e}^{-} / 1 \mathrm{H}^{+}$couple for DNA-bound MB comes from $\mathrm{pH}$ titrations, which yield a $30 \mathrm{mV} / \mathrm{pH}$ unit shift between $\mathrm{pH} 6-8$. Similar behavior has also been observed for MB in solution: Akkermans, R. P.; Roberts, S. L.; Marken, F.; Coles, B. A.; Wilkins, S. J.; Cooper, J. A.; Woodhouse, K. E.; Compton, R. G. J. Phys. Chem. B 1999, 103, 9987.

(83) Hagmar, P.; Pierrou, S.; Nielsen, P.; Norden, B.; Kubista, M. J. Biomol. Struct. Dyn. 1992, 9, 667-679.

(84) Rubinstein, I.; Rishpon, J.; Sabatani, E.; Redondo, A.; Gottesfeld, S. J. Am. Chem. Soc. 1990, 112, 6135.

(85) Finklea, H. O.; Snider, D. A.; Fedyk, J. Langmuir 1990, 6, 371376.

(86) Hunter, W. N.; Leonard, G. A.; Brown, T. ACS Symp. Ser. 1998, $682,77-90$ 73

(87) Luxon, B. A.; Gorenstein, D. G. Methods Enzymol. 1995, 261, 45-

(88) Forman, J. E.; Walton, I. D.; Stern, D.; Rava, R. P.; Trulson, M. O. ACS Symp. Ser. 1998, 682, 206-228.

(89) Peyret, N.; Seneviratne, P. A.; Allawi, H. T.; SantaLucia, J. Biochemistry 1999, 38, 3468-3477.

(90) SantaLucia, J. Proc. Natl. Acad. Sci. U.S.A. 1998, 95, 1460-1465.

(91) Bhattacharya, P. K.; Barton, J. K. J. Am. Chem. Soc. 2001, 123 8649-8656.

(92) Steenken, S.; Jovanovic, S. V. J. Am. Chem. Soc. 1997, 119, 617618 .

(93) Steenken, S.; Telo, J. P.; Novais, H. M.; Candeias, L. P. J. Am. Chem. Soc. 1992, 114, 4701-4709.

(94) Ha, D. H.; Nham, H.; Yoo, K.-H.; So, H.-M.; Lee, H.-Y.; Kawai, T. Chem. Phys. Lett. 2002, 355, 405-409. 